\title{
Jones, Martin (2019): Cities and regions in crisis. The political economy of sub-national economic development.
}

\author{
Margaret Cowell
}

Received: 3 June 2021 - Accepted: 11 June 2021 - Published online: 12 July 2021

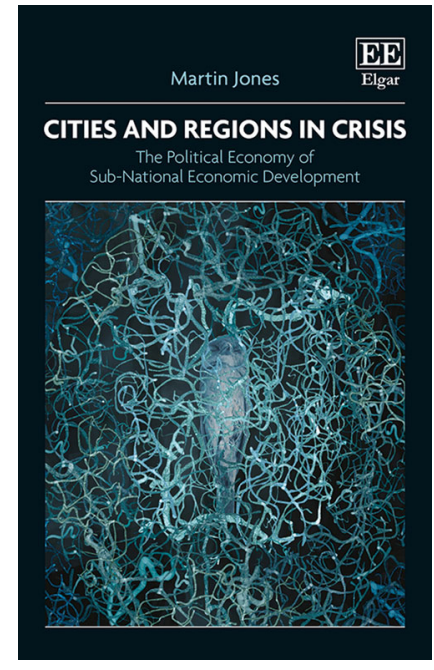

Though based on research that spans the last few decades, one would be hard-pressed to find a more timely and fitting contribution to the field of critical economic geography. As people and policymakers the world over grapple with the emerging and compounded crises of the COVID19 pandemic and pronounced racial and economic inequal-

Assoc. Prof. Dr. Margaret Cowell, School of Public and International Affairs, Virginia Polytechnic Institute and State University, 900 North Glebe Road, Arlington, VA, 22203, USA mmcowell@vt.edu

(c) (1) () 2021 Cowell; licensee oekom verlag. This Open Access article is published under a Creative Commons Attribution 4.0 International License. ities (Gaynor/Wilson 2020), many leaders in already lagging cities and regions are eager to learn more about the best ways to navigate these crises. While Martin Jones is narrowly focused here on sub-national geographies of economic governance in English cities and regions, he offers broadly applicable lessons about how policymakers deploy crisis spaces in order to frame and articulate problems and solutions in cities and regions.

Fitting of the book's title, Jones' introduction urges us to consider a number of insightful questions about cities and regions in crisis. For instance, what lessons can we learn from understanding the problems and opportunities seen in left-behind places? To confront protracted problems in these places, how do we harness the energy and passion of people who live and work there? And, perhaps most importantly, what type, scale, and geographies of mediation will allow for inclusive and sustainable economic development to occur in these places?

While Jones clearly points his finger at austerity and privatization as both cause and effect of sub-national economic development failures, one of the book's most important contributions is the thoughtful analysis and myriad case studies he brings to bear on these arguments. We often hear heated commentary on the ills of devolution (Pike/Tomaney 2009), but few have provided such knowledgeable or rich interpretations as Jones does here. By starting from the premise that decentralization is not working, Jones urges us to consider where we go from here.

The book begins with a rich description of the evolution of local economic development in England, with additional insights from the United States and Europe. It has generally been the case that when it comes to local economic development, a sense of 'chronic short termism' has resulted in the creation of layers of duplicative economic partnerships 
replete with private sector domination and fuzzy notions of accountability. One of the book's most compelling arguments is the idea that these state interventions have created a crisis legacy in which the perpetual restructuring, layering of fuzzy state-led initiatives, and erosion of elected and representative models of democracy mainly seek to respond to problems caused by the state's own interventions. This argument remains central to the book as Jones takes us on a journey from New Localism (Part I), to New Regionalism (Part II), and what he calls the New New Localism (Part III).

In Part I, Jones walks us through a nuanced discussion of the important difference between government and governance (Chapter 2), an overview of the contradictions and irrationalities of capitalism and the ways in which neoliberalization of the city has led us to our contemporary 'crisis of crisis management' (Chapter 3), and a thorough review of the evolution of the Employment Zones initiative, which was seen as a hallmark of the New Labour employability agenda.

Part II includes a history of the experimental Regional Development Agencies program, emblematic of the UKwide devolution agenda (Chapter 5), an insightful discussion of the difference between state-driven functional regionalism and pre-existing or bottom-up civil society regionalism using the Midlands as a case study (Chapter 6), and an analysis of the emerging city-region approach to management of the Sheffield city-region's labour market (Chapter 7). Ultimately, Jones asserts that the New Regionalism approach focuses mainly on the idea that site- and place-specific interventions can anchor and ultimately nurture robust forms of economic development. He questions, however, whether such approaches will actually result in positive economic development dividends.

Jones begins Part III with a call to reconsider the localities debate, namely as a way to increase our understanding of economic and social development. Near the end of Chapter 8, Jones offers a historical overview of the term 'localities', which I would argue is an understated but important contribution to the book. Thereafter he seeks to identify the missing elements from the 'Northern Powerhouse' playbook for economic growth and social democracy by looking at how civil society actors in Sheffield and Manchester have grappled with devolution. Part III ends with a word of caution about city-regions becoming 'post-political contested spaces' in which shifts in the power relations between capital and labour has resulted in the weakening of collective bargaining and the casualization of employment.

If you are well-acquainted with existing, and seemingly ubiquitous, attempts to theorize neoliberalism (Birch/
Springer 2019), you may be tempted to skip ahead to the final section (Part IV), where Jones offers up some potential alternatives. However, I would urge you to avoid doing so, as earlier sections provide rich detail, illuminating case studies, and thoughtful critiques that leave readers wanting to know more about how we can do better. While Chapter 11 stops short of providing concrete recommendations or stepby-step strategies to cultivate inclusive growth in left-behind places, it does provide the beginning of a roadmap to incorporating third and voluntary sector organizations for a more inclusive model of governance. This preliminary structure is much appreciated, as is the discussion in Chapter 12 of Denmark's welfare-through-work program. The paperback edition ends with a timely update on sub-national economic development in the context of Brexit and implications for Stoke-on-Trent, reminding us of the fragility of the neoliberal economic social contract.

Overall, Cities and Regions in Crisis presents a rich and insightful analysis of urban and regional governance in England. Jones has rather successfully curated a body of work that not only documents, but also questions the notion of crises in the context of uneven development and, more specifically, in left behind places. It manages to be both comprehensive and inclusive, thoroughly researched and accessible, and highly theorized and policy relevant. It should be recognized as an important contribution to the fields of critical economic and political geographies, at what is ostensibly a defining moment for subnational economic development.

Full reference of reviewed title: Jones, Martin (2019): Cities and regions in crisis. The political economy of sub-national economic development. Cheltenham: Edward Elgar Publishing. 320 pp.

\section{References}

Birch, K.; Springer, S. (2019): Peak neoliberalism? Revisiting and rethinking the concept of neoliberalism. In: Ephemera 19, 3, 467-485.

Gaynor, T.S.; Wilson, M.E. (2020): Social vulnerability and equity: The disproportionate impact of COVID-19. In: Public Administration Review 80, 5, 832-838. https:// doi.org/10.1111/puar.13264

Pike, A.; Tomaney, J. (2009): The state and uneven development: the governance of economic development in England in the post-devolution UK. In: Cambridge Journal of Regions, Economy and Society 2, 1, 13-34. https:// doi.org/10.1093/cjres/rsn025 